\title{
Estimasi asupan indeks glikemik dan beban glikemik dengan kontrol gula darah pasien diabetes melitus tipe 2
}

Estimated dietary glycemic index and glycemic load with blood sugar control patients with type 2 diabetes mellitus

\author{
Sinta Mukti Permatasari ${ }^{1}$, Toto Sudargo ${ }^{2}$, Luthfan Budi Purnomo ${ }^{3}$ \\ ${ }^{1}$ Minat Utama Gizi dan Kesehatan, Program Studi S2 Ilmu Kesehatan Masyarakat Fakultas Kedokteran Universitas Gadjah Mada \\ ${ }^{2}$ Departemen Gizi Kesehatan, Fakultas Kedokteran Universitas Gadjah Mada \\ ${ }^{3}$ Bagian Ilmu Penyakit Dalam, Rumah Sakit Umum Pusat Dr. Sardjito
}

\begin{abstract}
Background: Non-infectious disease (NID) has become a public health problem both globally, regionally, nasionally, and locally. One of NID that takes a lot of attention is diabetes mellitus (DM). Risk of complication is higher due to lack of attention to lifestyle including diet. The concept of the glycemic index classifies carbohydrate is considered better in controlling blood sugar. However, some studies say otherwise. Therefore, research needs to be done by combining carbohydrate quantity concept (glycemic load) and glycemic index. Objective: To identify the relationship between estimated dietary glycemic index (GI) and glycemic load (GL) with blood sugar control, as well as to identify other factors associated with glycemic control of patients with type 2 diabetes mellitus. Method: This is an observational study with cross-sectional design. The population study were all outpatients with type 2 diabetes mellitus in Dr. Sardjito hospital Yogyakarta in 2014. Sampling method using a consecutive sampling with sample size of 79 people. Interviews regarding the identity of the respondents through questionnaires, physical activity (IPAQ), and semi-quantitative food frequency (SQFFQ). Blood sugar control (HbAlC) obtained from respondent's medical record. The data were processed using univariable analysis (descriptive), bivariate (Chi-Square), and multivariate (GLM). Results: Most respondents were blood sugar

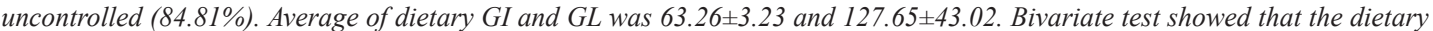
GI and GL each has a RP value 1.023 and $1.002(p<0.05)$ with HbA1C. The prevalence of uncontrolled blood sugar 4.18 times greater in respondents who doesn't have appropriate eating schedule. Duration of diabetes, nutritional status, physical activity, and education level did not significantly influence HbAlC ( $p>0.05)$. Conclusion: There is a relationship between dietary GI, GL, and eating schedule with blood sugar control (HbAlC), but there was no correlation between duration of diabetes, nutritional status, physical activity, and education level with blood sugar control (HbAlC).
\end{abstract}

KEY WORDS: dietary glycemic index; dietary glycemic load; type 2 diabetes mellitus

\begin{abstract}
ABSTRAK
Latar belakang: Penyakit tidak menular (PTM) sudah menjadi masalah kesehatan masyarakat baik secara lokal, regional, nasional, dan global. Salah satu PTM yang menyita banyak perhatian adalah diabetes melitus (DM). Resiko komplikasi semakin tinggi akibat kurang memperhatikan pola hidup termasuk pola makan. Konsep indeks glikemik dengan mengelompokkan karbohidrat dianggap lebih baik dalam mengontrol gula darah. Namun beberapa penelitian mengatakan sebaliknya. Oleh karena itu, perlu dilakukan penelitian dengan menggabungkan kuantitas karbohidrat beban glikemik (BG) dengan indeks glikemik (ID). Tujuan: Mengetahui hubungan estimasi asupan IG dan BG dengan kontrol gula darah, serta mengetahui faktor-faktor lain yang berhubungan dengan kontrol gula darah pasien DM tipe 2. Metode: Penelitian observasional dengan desain cross sectional. Populasi penelitian adalah semua pasien rawat jalan DM tipe 2 di RSUP Dr. Sardjito Yogyakarta tahun 2014. Pemilihan sampel menggunakan consecutive sampling dengan jumlah sampel 79 orang. Wawancara melalui kuesioner mengenai identitas, aktivitas fisik (IPAQ), dan semi quantitative food frequency (SQFFQ). Kontrol gula darah (HbA1C) didapatkan dari catatan medis responden. Data dianalisis secara bivariat (Chi-Square) dan multivariat (GLM). Hasil: Sebagian besar responden tidak terkontrol kadar gulanya (84,81\%).

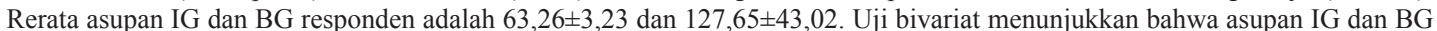
masing-masing memiliki nilai PR 1,023 dan 1,002 ( $<<0,05)$ terhadap HbA1C. Prevalensi gula darah tidak terkontrol 4,18 kali lebih besar pada kelompok jadwal makan tidak sesuai. Lama terdiagnosis DM, status gizi, aktivitas fisik, dan tingkat pendidikan tidak
\end{abstract}

Korespondensi: Sinta Mukti Permatasari, Minat Utama Gizi dan Kesehatan, Program Studi S2 Ilmu Kesehatan Masyarakat Fakultas Kedokteran Universitas Gadjah Mada, Jl. Farmako, Sekip Utara, Yogyakarta 55281, e-mail: sinta.mukti.p@gmail.com 
signifikan terhadap HbA1C ( $>>0,05)$. Simpulan: Terdapat hubungan antara asupan IG, BG, dan jadwal makan terhadap kontrol gula darah. Namun, tidak terdapat hubungan antara lama terdiagnosis DM, status gizi, aktivitas fisik, dan tingkat pendidikan dengan kontrol gula darah.

KATA KUNCI: asupan indeks glikemik; asupan beban glikemik; DM tipe 2

\section{PENDAHULUAN}

Penyakit tidak menular (PTM) sudah menjadi masalah kesehatan masyarakat, baik secara lokal, regional, nasional, dan global. Hal ini dikarenakan PTM menjadi penyebab utama kematian secara global. Salah satu dari 10 besar PTM yang menyita banyak perhatian adalah diabetes melitus (DM). Proporsi orang dengan DM diduga akan meningkat menjadi 333 juta $(6,3 \%)$ pada tahun 2025 (1). American Diabetes Association (ADA) menyatakan bahwa pola hidup memegang peranan penting dalam mencegah dan mengatasi penyakit DM (2). Pola makan yang baik dan aktivitas fisik dianggap mampu memperbaiki kontrol gula darah sehingga kualitas hidup orang dengan DM menjadi lebih baik. Selain pola makan dan aktivitas fisik, faktor lain dianggap berperan dalam kontrol gula darah, beberapa diantaranya adalah lama terdiagnosis DM, status gizi, tingkat pengetahuan/ pendidikan. Semakin lama seseorang didiagnosis dengan DM, akan semakin sulit untuk menjaga kontrol gula darah (3).

David Jenkins, seorang Profesor Gizi di Universitas Toronto, Kanada, mengembangkan sebuah konsep dalam diet DM. Konsep ini dikenal dengan indeks glikemik yaitu diet dengan mengelompokkan karbohidrat. Meskipun diet IG dinyatakan baik, akan tetapi beberapa penelitian mengatakan sebaliknya (4-6). Adanya kontroversi keefektifan diet indeks glikemik tersebut sehingga beberapa penelitian telah mengembangkan istilah baru untuk melengkapi konsep IG yaitu beban glikemik (BG). Konsep BG mengatasi kekurangan konsep IG dengan mempertimbangkan tidak hanya jenis IG tapi juga jumlah dari makanan yang tertelan (7).

Dengan demikian, perlu dilakukan penelitian lebih lanjut yang lebih fokus pada pengaruh IG dan BG pada pasien DM, sementara diketahui bahwa hubungan diet 3J (jadwal, jumlah, jenis) dengan mempertimbangkan jenis pangan berdasarkan IG dan BG dinyatakan berpengaruh terhadap kadar gula darah. Hal ini akan menghasilkan gambaran diet IG dan BG yang seperti apa yang akan memberikan pengaruh nyata terhadap pasien dengan DM. Tujuan penelitian ini adalah untuk mengetahui hubungan antara estimasi asupan IG dan BG, serta faktor-faktor lain yang berhubungan dengan kontrol gula darah pasien DM tipe 2.

\section{BAHAN DAN METODE}

Penelitian ini adalah penelitian observasional dengan desain cross-sectional. Penelitian ini dilakukan di Klinik Diabetes Rumah Sakit Umum Pusat (RSUP) Dr. Sardjito Yogyakarta pada bulan Februari - Juni 2014. Populasi penelitian ini adalah semua pasien rawat jalan DM tipe 2 di RSUP Dr. Sardjito Yogyakarta tahun 2014. Pemilihan sampel menggunakan consecutive sampling dengan kriteria yaitu pasien rawat jalan DM tipe 2, bersedia mengikuti jalannya penelitian, tidak menderita gangguan gigi dan mulut, tidak sedang menjalani diet khusus, dan tidak hamil.

Variabel bebas dalam penelitian ini adalah asupan indeks glikemik dan beban glikemik. Data asupan makan diperoleh dari semi quantitative food frequency (SQFFQ), responden diwawancara seberapa sering mereka mengkonsumsi makanan selama 1 bulan terakhir dan seberapa banyak konsumsinya dalam satu kali makan. Hasil tersebut kemudian dikonversi dalam gram (g) dan disesuaikan dengan IG dan BG berdasarkan international table of glycemic index (8). Bahan makanan dikategorikan memiliki IG rendah jika <55; sedang 55-70; dan tinggi $>70$ (8) sementara asupan BG dikategorikan rendah untuk laki-laki apabila <133; sedang 133-188; dan tinggi $>188$ sedangkan untuk perempuan dikategorikan rendah bila $<143$; sedang 143-165; dan tinggi $>165$ (9). Variabel terikat adalah kontrol gula darah menggunakan data sekunder (uji laboratorium menggunakan kategori HbA1C) maksimal 3 bulan sebelum pengambilan data.

Variabel luar adalah jadwal makan, lama terdiagnosis DM, status gizi, aktivitas fisik, dan tingkat pendidikan. Data jadwal makan, lama terdiagnosis DM, 
dan tingkat pendidikan diperoleh dengan kuesioner. Jadwal makan dikategorikan menjadi sesuai (jarak antar makan 3 jam, dengan makan utama dan snack) dan tidak sesuai (jarak antar makan tidak ada/tidak ada snack). Lama terdiagnosis DM adalah lama waktu (durasi) responden menderita DM tipe 2 sesuai dengan diagnosis dokter. Tingkat pendidikan adalah tingkat pendidikan formal yang ditempuh oleh responden yang dibagi dalam tiga kategori yaitu rendah (tidak sekolah), sedang (sekolah sampai dengan tamat SMA), dan tinggi (lanjut sekolah setelah tamat SMA). Data status gizi dilakukan dengan menimbang berat badan dan mengukur tinggi badan kemudian dilakukan perhitungan dengan indikator indeks massa tubuh (IMT). Data aktivitas fisik diketahui dengan menggunakan International Physical Activity Questionnare (IPAQ) dengan skor yang diberikan adalah rendah (<600MET-menit/minggu), sedang (600-3000 MET-menit/minggu), dan tinggi (>3000 MET-menit/ minggu) (10).

Analisis data dengan prevalensi rasio (PR) untuk mengetahui kekuatan hubungan antarvariabel dan uji Chi-Square digunakan untuk uji signifikansi. Analisis multivariat dilakukan untuk mengetahui hubungan variabel bebas dan variabel terikat secara bersama-sama dengan mengontrol variabel luar. Uji yang digunakan adalah generalized linear regression model dengan distribusi normal, logaritma link, dan robust variance (GLM) dengan tingkat kemaknaan $\mathrm{p}<0,05$ dengan CI $95 \%$.

\section{HASIL}

Karakteristik responden berdasarkan jenis kelamin, pekerjaan, dan umur dapat dilihat pada Tabel 1 yang menunjukkan bahwa sebagian besar pasien DM yang menjadi responden penelitian ini berjenis kelamin lakilaki, tidak bekerja, dan berada pada rentang usia 50-64 tahun. Sementara pada Tabel 2 menunjukkan bahwa ratarata IG yang dikonsumsi oleh responden termasuk dalam kategori sedang sedangkan rerata asupan BG responden termasuk dalam kategori rendah.

Pasien dikatakan terkontrol gula darahnya jika nilai $\mathrm{HbA1C}$ selama maksimal 3 bulan yang lalu adalah kurang dari atau sama dengan $6,5 \%$ dan pasien yang tidak terkontrol gula darahnya jika nilai $\mathrm{HbAlC}$ lebih dari 6,5\% (11). Tabel 3 menunjukkan bahwa sebagian besar pasien DM pada penelitian ini tidak terkontrol kadar gulanya.

Hubungan asupan indeks glikemik dengan kontrol gula darah (HbA1C) memiliki nilai PR sebesar 1,023 dan bermakna secara statistik dengan nilai $\mathrm{p}<0,05(95 \%$ CI 1,01-1,04) (Tabel 4). Interpretasi dari hasil tersebut adalah setiap penambahan satu unit indeks glikemik, maka nilai $\mathrm{HbA1C}$ akan semakin meningkat 2,3\%, sehingga kontrol gula darah akan semakin buruk.

Hasil analisis untuk hubungan asupan beban glikemik dengan kontrol gula darah (HbA1C) diperoleh nilai PR sebesar 1,002 dan bermakna secara statistik $(\mathrm{p}<0,05 ; 95 \% \mathrm{CI}=1,000-1,003)$. Interpretasi dari hasil tersebut adalah setiap penambahan satu unit beban glikemik, maka nilai HbA1C akan semakin meningkat $0,2 \%$ sehingga kontrol gula darah akan semakin buruk. Lebih lanjut, hubungan antara jadwal makan dengan kontrol gula darah (HbA1C) memiliki nilai PR sebesar 4,18 dan bermakna secara statistik ( $\mathrm{p}<0,05 ; 95 \% \mathrm{CI}=1,23$ -

Tabel 1. Karakteristik responden penelitian berdasarkan jenis kelamin, pekerjaan, dan umur

\begin{tabular}{lcc}
\hline Karakteristik responden & $\mathbf{n}$ & $\mathbf{\%}$ \\
\hline Jenis kelamin & & \\
$\quad$ Laki-laki & 46 & 58,23 \\
$\quad$ Perempuan & 33 & 41,77 \\
Pekerjaan & & \\
TNI/PNS & 12 & 15,19 \\
Wiraswasta & 15 & 18,99 \\
Swasta & 4 & 5,06 \\
Tidak bekerja & 48 & 60,76 \\
Umur (tahun) & & \\
$30-49$ & 10 & 12,66 \\
$50-64$ & 50 & 63,29 \\
$65-80$ & 17 & 21,52 \\
$>80$ & 2 & 2,53 \\
\hline
\end{tabular}

Tabel 2. Distribusi asupan indeks glikemik dan beban glikemik

\begin{tabular}{lccccc}
\hline Variabel & Minimum & Maksimal & Rerata & Median & SD \\
\hline Asupan $\mathrm{IG}^{1}$ & 53,67 & 71,58 & 63,26 & 63,33 & 3,23 \\
Asupan $\mathrm{BG}^{2}$ & 41,78 & 287,46 & 127,65 & 121,59 & 43,02 \\
\hline
\end{tabular}

${ }^{1} \mathrm{IG}=$ indeks glikemik; ${ }^{2} \mathrm{BG}=$ beban glikemik 
Tabel 3. Distribusi kontrol gula darah, jadwal makan, lama terdiagnosis DM, status gizi, aktivitas fisik, dan tingkat pendidikan

\begin{tabular}{|c|c|c|}
\hline Variabel & $\mathbf{n}$ & $\%$ \\
\hline \multicolumn{3}{|l|}{ Kontrol gula darah } \\
\hline Terkontrol & 12 & 15,19 \\
\hline Tidak terkontrol & 67 & 84,81 \\
\hline \multicolumn{3}{|l|}{ Jadwal makan } \\
\hline Sesuai & 9 & 11,39 \\
\hline Tidak sesuai & 70 & 88,61 \\
\hline \multicolumn{3}{|l|}{ Lama terdiagnosis DM } \\
\hline$<5$ tahun & 24 & 30,38 \\
\hline 5-9 tahun & 22 & 27,85 \\
\hline$\geq 10$ tahun & 33 & 41,77 \\
\hline \multicolumn{3}{|l|}{ Status gizi } \\
\hline Normal & 32 & 40,51 \\
\hline Lebih & 9 & 11,39 \\
\hline Obesitas & 38 & 48,10 \\
\hline \multicolumn{3}{|l|}{ Aktivitas fisik } \\
\hline Rendah & 38 & 48,10 \\
\hline Sedang & 39 & 49,37 \\
\hline Tinggi & 2 & 2,53 \\
\hline \multicolumn{3}{|l|}{ Tingkat pendidikan } \\
\hline Rendah & 7 & 8,86 \\
\hline Sedang & 47 & 59,49 \\
\hline Tinggi & 25 & 31,65 \\
\hline
\end{tabular}

14,12). Interpretasi dari hasil tersebut adalah prevalensi pasien DM tipe 2 dengan kadar gula darah tidak terkontrol pada kelompok yang memiliki jadwal makan tidak sesuai 4,18 kali lebih besar daripada kelompok yang memiliki jadwal makan sesuai (Tabel 5).

Hasil analisis multiraviat menunjukkan bahwa variabel lama terdiagnosis DM, status gizi, aktivitas fisik, dan tingkat pendidikan memiliki hubungan yang lemah terhadap kontrol gula darah sehingga secara statistik tidak signifikan. Model akhir yang dipilih adalah model 5 karena terdapat 1 variabel yang signifikan $(p<0,05)$ dengan nilai BIC yang lebih rendah Nilai BIC yang semakin rendah menunjukkan bahwa model tersebut semakin baik (uji goodness of fit). Varians pada model 5 juga lebih kecil sehingga presisinya lebih baik. Hasil analisis

Tabel 4. Tabulasi silang antara estimasi asupan indeks glikemik dengan kontrol gula darah

\begin{tabular}{lccc}
\hline Variabel & PR & $\mathbf{9 5 \%}$ CI & p value \\
\hline Asupan IG & 1,023 & $1,01-1,04$ & $0,001^{*}$ \\
Asupan BG & 1,002 & $1,000-1,003$ & $0,03^{*}$ \\
\hline
\end{tabular}

*signifikan $(\mathrm{p}<0,05)$

Tabel 5. Tabulasi silang antara jadwal makan, lama terdiagnosis DM, status gizi, aktivitas fisik, dan tingkat pendidikan dengan kontrol gula darah

\begin{tabular}{|c|c|c|c|c|c|c|c|}
\hline \multirow{3}{*}{ Variabel } & \multicolumn{4}{|c|}{ Kontrol gula darah } & \multirow{3}{*}{ PR } & \multirow{3}{*}{$95 \%$ CI } & \multirow{3}{*}{$\mathbf{p}$} \\
\hline & \multicolumn{2}{|c|}{ Tidak terkontrol } & \multicolumn{2}{|c|}{ Terkontrol } & & & \\
\hline & $\mathbf{n}$ & $\%$ & $\mathbf{n}$ & $\%$ & & & \\
\hline \multicolumn{8}{|l|}{ Jadwal makan } \\
\hline Tidak sesuai & 65 & 82,28 & 5 & 6,33 & 4,18 & $1,23-14,21$ & $0,001 *$ \\
\hline Sesuai & 2 & 2,53 & 7 & 8,86 & & & \\
\hline \multicolumn{8}{|c|}{ Lama terdiagnosis DM } \\
\hline$<5$ tahun & 20 & 25,32 & 4 & 5,06 & 1,00 & & \\
\hline 5-9 tahun & 20 & 25,32 & 2 & 2,53 & 1,09 & $0,87-1,36$ & 0,45 \\
\hline$\geq 10$ tahun & 27 & 34,17 & 6 & 7,59 & 0,98 & $0,77-1,25$ & 0,88 \\
\hline \multicolumn{8}{|l|}{ Status Gizi } \\
\hline Normal & 28 & 35,44 & 4 & 5,06 & 1,00 & & \\
\hline Lebih & 8 & 10,13 & 1 & 1,27 & 1,02 & $0,78-1,32$ & 0,91 \\
\hline Obesitas & 31 & 39,24 & 7 & 8,86 & 0,93 & $0,76-1,14$ & 0,49 \\
\hline \multicolumn{8}{|l|}{ Aktivitas fisik } \\
\hline Rendah & 34 & 43,04 & 4 & 5,06 & 1,00 & & \\
\hline Sedang & 31 & 39,24 & 8 & 10,13 & 0,89 & $0,73-1,08$ & 0,23 \\
\hline Tinggi & 2 & 2,53 & 0 & 0 & 1,12 & $1,00-1,25$ & 0,63 \\
\hline \multicolumn{8}{|l|}{ Tingkat pendidikan } \\
\hline Rendah & 6 & 7,59 & 1 & 1,27 & 1,00 & & \\
\hline Sedang & 40 & 50,63 & 7 & 8,86 & 0,99 & $0,72-1,37$ & 0,97 \\
\hline Tinggi & 21 & 26,58 & 4 & 5,06 & 0,98 & $0,69-1,39$ & 0,91 \\
\hline
\end{tabular}

*signifikan $(\mathrm{p}<0,05)$ 
Sinta Mukti Permatasari, dkk: Estimasi asupan indeks glikemik dan beban glikemik dengan kontrol gula darah pasien diabetes melitus tipe 2

Tabel 6. Analisis multivariat

\begin{tabular}{lccc}
\hline \multicolumn{1}{c}{ Variabel } & PR & p & $\mathbf{9 5 \% ~ C I ~}$ \\
\hline Asupan IG & 1,02 & 0,072 & $0,99-1,04$ \\
Asupan BG & 1,00 & 0,489 & $0,99-1,00$ \\
Jadwal makan & 3,97 & $0,028^{*}$ & $1,16-13,5$ \\
\hline
\end{tabular}

*signifikan $(\mathrm{p}<0,05)$

menunjukkan bahwa jadwal makan mempengaruhi hubungan antara asupan IG dan BG dengan kontrol gula darah (HbA1C) pada alfa 5\% (Tabel 6).

\section{BAHASAN}

\section{Hubungan antara estimasi asupan IG dan BG dengan kontrol gula darah (HbA1C)}

Hubungan asupan IG dan kontrol gula darah adalah signifikan secara statistik. Hasil ini serupa dengan beberapa penelitian yang ada sebelumnya, dengan penurunan $\mathrm{HbA} 1 \mathrm{C}$ bervariasi antara $0,2 \%$ dan $0,27 \%$ $(12,13)$. Alasan yang menyebabkan hubungan ini menjadi signifikan yaitu fungsi IG itu sendiri terhadap respon gula darah. Indeks glikemik adalah tingkatan pangan yang disesuaikan dengan kecepatan pangan tersebut dalam menaikkan gula darah sehingga semakin tinggi I makanan yang dikonsumsi, maka peningkatan gula darah dalam tubuh semakin cepat. Jika hal ini menjadi pola makan sehari-hari, maka gula darah dalam tubuh cenderung tinggi setiap saat. Hal inilah yang nantinya berpengaruh pada kontrol gula darah responden (semakin tidak terkontrol).

Penurunan $\mathrm{HbA}$ 1C yang tidak terlalu besar pada beberapa penelitian ini justru memiliki relevansi klinis yang signifikan. Berdasarkan The United Kingdom Prospective Diabetes Study, penurunan 1\% HbA1C menurunkan risiko kematian terkait diabetes sebesar $21 \%$, $14 \%$ untuk myocardial infarction, dan 37\% komplikasi makrovaskular diabetes (14). Demikian juga hubungan asupan BG dan kontrol gula darah adalah signifikan secara statistik. Efek menguntungkan ini dapat dijelaskan karena BG merupakan representatif dari jumlah makanan yang dikonsumsi dalam satu kali makan, yiatu besar kuantitas inilah yang memberikan efek langsung terhadap peningkatan gula darah. Beban glikemik memberikan pengertian bahwa walaupun jenis IG makanan itu tinggi, jika dikonsumsi dalam jumlah sedikit, efeknya akan berbeda dengan mengonsumsinya dalam jumlah banyak. Oleh karena itu, BG dapat memperhitungkan perubahan diet terkait dengan kontrol gula darah. Apabila kontrol gula darah buruk, makanan jenis IG tinggi dan rendah dapat disesuaikan jumlahnya.

Hasil ini berbeda dengan beberapa penelitian yang telah ada sebelumnya bahwa asupan BG rendah berhubungan dengan kontrol gula darah yang buruk, tetapi hasil penelitian tidak signifikan $(12,15,16)$. Hal ini bisa disebabkan oleh subjek yang diteliti adalah orang yang tidak diabetes. Efek menguntungkan diet rendah IG atau BG tidak konsisten pada populasi non-diabetes karena mereka kurang rentan terhadap perubahan dinamika insulin terhadap gula darah. Hal ini dikemukakan oleh penelitian sebelumnya bahwa efek menguntungkan diet IG dan BG rendah hanya ketika konsentrasi gula darah puasa lebih tinggi dari $6 \mathrm{mmol} / \mathrm{L}$ (16). Dengan demikian, efek diet IG dan BG rendah terhadap kontrol gula darah yang lebih baik hanya bisa ditunjukkan pada subjek yang telah mengalami gangguan toleransi glukosa atau telah menderita DM.

\section{Hubungan antara jadwal makan dengan kontrol gula darah (HbA1C)}

Hasil penelitian ini membuktikan bahwa terdapat hubungan yang signifikan antara jadwal makan dengan kontrol gula darah (HbA1C). Hubungan yang signifikan ini sesuai dengan beberapa penelitian yang telah ada $(17,18)$. Penjelasan dari hubungan ini adalah karena jadwal makan berhubungan dengan naik turunnya gula darah. Jadwal makan yang lebih sedikit (jarang/tidak teratur) akan membuat fluktuasi gula darah menjadi sangat tajam. Jika hal ini menjadi pola konsumsi seharihari, maka dapat membuat gula darah tidak terkontrol. Fluktuasi yang tidak beraturan ini juga sangat berbahaya bagi penderita diabetes (kondisi hiperglikemi dan hipoglikemi).

Analisis multivariat menunjukkan adanya hubungan yang signifikan untuk variabel jadwal makan. Hal ini membuktikan bahwa jadwal makan berhubungan langsung dengan kontrol gula darah. Jadwal makan yang tidak sesuai akan berpengaruh langsung terhadap kontrol gula darah yang buruk, walaupun terdapat faktor 


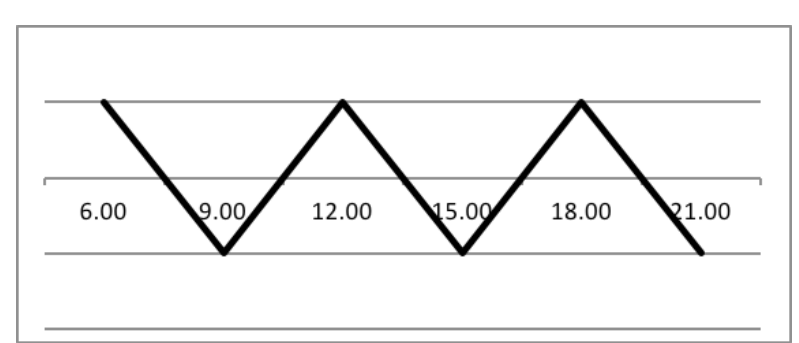

Gambar 1. Fluktuasi gula darah tanpa snack

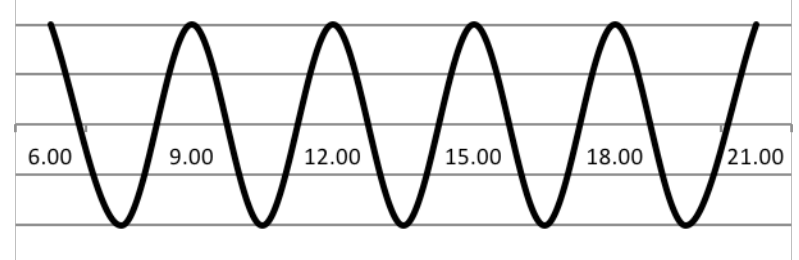

Gambar 2. Fluktuasi gula darah dengan snack

lain yang mengganggu atau mempengaruhi kontrol gula darah. Seperti yang telah dijelaskan sebelumnya, jadwal makan berhubungan dengan naik turunnya gula darah. Fluktuasi gula darah pasien DM dengan pola makan tanpa selingan/snack dapat dijelaskan pada Gambar 1. Orang dengan pola makan yang tidak teratur (tidak terjadwal) atau dengan jarak makan terlalu lama/jauh (misalnya 6 jam, yaitu makan utama 3 kali tanpa selingan/ snack), berisiko tinggi mengalami hipoglikemi maupun hiperglikemi, berkaitan dengan fluktuasi gula darah yang terlalu tajam. Sementara orang dengan pola makan teratur (terjadwal) atau dengan jarak makan yang sering (misalnya 3 jam, yaitu makan utama 3 kali dan selingan 2-3 kali), memiliki fluktuasi gula darah yang lebih baik sehingga risiko hipoglikemi atau hiperglikemi akan minimal terjadi (Gambar 2).

Pada penelitian ini, pola makan yang tidak teratur, hubungannya dengan jadwal makan yang tidak sesuai dapat disebabkan oleh ketidaktahuan responden terhadap prinsip diet DM. Walaupun responden telah lama menderita DM, hampir sebagian besar responden tidak tahu mengenai bagaimana mengatur jadwal makan. Ketidaktahuan responden ini dapat diartikan tidak pernah diberikan penjelasan diet atau pernah diberikan tetapi dilupakan. Penjelasan diet DM lebih baik jika selalu diberikan berkala sesuai dengan anjuran ahli gizi (misalnya satu bulan sekali). Hal ini dapat membantu responden menerapkan prinsip diet dengan benar sehingga kontrol gula darah akan semakin baik. Hal ini juga dijelaskan oleh penelitian sebelumnya yang menyatakan bahwa responden dengan pola makan yang kurang baik dapat disebabkan ketidakpatuhan pada prinsip diet yang diberikan atau pengetahuan tentang prinsip diet masih sangat rendah (18).

\section{Hubungan antara lama terdiagnosis DM dengan kontrol gula darah (HbA1C)}

Hasil penelitian ini menyatakan bahwa hubungan lama terdiagnosis DM dengan kontrol gula darah (HbA1C) secara statistik tidak signifikan. Hasil ini berbeda dengan beberapa penelitian sebelumnya yang menyatakan bahwa semakin lama orang menderita DM, maka semakin susah mengontrol kadar gula darahnya (3,19-22). Penelitian lain justru menyatakan sebaliknya, kontrol gula darah yang buruk banyak terjadi pada orang dengan lama menderita DM lebih pendek (23). Terdapat banyak kemungkinan yang dapat menjadi penyebab hubungan antara lama terdiagnosis DM dengan kontrol gula darah ini tidak signifikan. Pertama, variabel ini mengandalkan diagnosis dokter yang sangat tergantung pada kunjungan pasien sehingga masalah utamanya adalah ketepatan waktu diagnosis awal. Hal ini menyebabkan data mengenai ketepatan lama responden terdiagnosis DM menjadi kurang valid. Orang dengan diabetes seringkali tidak dapat merasakan gejalanya pada stadium awal dan tetap tidak terdiagnosis selama bertahun-tahun sampai terjadi bermacam-macam komplikasi dari penyakit ini (24).

Kemungkinan kedua, keterlambatan diagnosis menyebabkan perawatan diri/self care pasien menjadi terlambat. Seperti diketahui bahwa self care meningkatkan kualitas hidup seseorang yang sangat dipengaruhi oleh pengetahuan, depresi, perilaku terhadap sakit, lama penyakit yang diderita, dan faktor ekonomi (25). Keterlambatan self care pasien menyebabkan orang yang terlambat terdiagnosis termasuk dalam kategori $<5$ tahun, akan memiliki kontrol gula darah yang buruk. Kemungkinan ketiga, pengobatan yang lebih baik. Berdasarkan National Health and Nutrition Examination Survey (NHANES) tahun 1999-2000, perbedaan lama menderita DM dengan peningkatan glikemia tidak 
mengalami perubahan yang signifikan (21). Hal ini dapat disebabkan penggunaan obat untuk kontrol gula darah yang lebih besar (pengobatan yang lebih baik).

\section{Hubungan antara status gizi dengan kontrol gula darah (HbA1C)}

Hubungan status gizi dengan kontrol gula darah (HbA1C) secara statistik tidak signifikan. Berbeda dengan beberapa penelitian sebelumnya yang menemukan hubungan signifikan antara status gizi dengan kontrol gula darah $(19,22)$, tetapi ditemukan juga pada banyak penelitian lain yang menyatakan tidak signifikan $(21,26,27)$. Penelitian sebelumnya menyatakan bahwa HbA1C dipengaruhi secara signifikan oleh parameter sindrom metabolik (GDP, HDL, tekanan darah, trigliserida, lingkar pinggang), tetapi tidak berhubungan dengan tingkat obesitas (25).

Penelitian serupa menyimpulkan, kontrol gula darah yang buruk justru terjadi pada orang dengan IMT yang lebih rendah (tidak obes) (25). Dalam penelitian ini, responden yang tidak terkontrol gula darahnya juga banyak terjadi pada responden dengan IMT normal (tidak obes). Penjelasan dari hasil ini adalah treatment untuk meningkatkan kontrol gula darah dapat menyebabkan peningkatan berat badan, bukan sebaliknya. Orang yang menjalani treatment untuk kontrol gula darah akan memiliki IMT yang lebih tinggi seiring dengan peningkatan kontrol gula darahnya.

\section{Hubungan antara aktivitas fisik dengan kontrol gula darah (HbA1C)}

Penelitian ini menemukan hubungan yang tidak signifikan antara aktivitas fisik dengan kontrol gula darah (HbA1C). Hasil ini berbeda dengan beberapa penelitian sebelumnya $(28,29)$ yang menyatakan bahwa peningkatan aktivitas fisik melalui pelatihan atau olahraga akan meningkatkan sensitivitas hormon insulin sehingga gula darah lebih terkontrol. Akan tetapi, beberapa penelitian justru menyatakan sebaliknya $(29,30)$. Hal lain yang perlu diperhatikan dari penelitian ini adalah sebagian besar responden tidak melakukan aktivitas fisik yang intensif. Aktivitas fisik yang dilakukan hanya sebatas meluangkan waktu untuk berjalan kaki/jalan santai. Hal ini dibuktikan dengan jumlah responden dengan aktivitas fisik yang memiliki skor cukup tinggi (kombinasi jogging, senam, dan bersepeda) hanya berjumlah 2 orang. Penelitian sebelumnya menyatakan bahwa aktivitas fisik yang lebih berat mungkin lebih berpengaruh terhadap kontrol gula darah (31). Disebutkan juga bahwa responden yang melakukan senam, kontrol gula darahnya lebih baik daripada yang tidak melakukan senam (32).

Pada penelitian ini, frekuensi memegang peranan penting dalam menentukan kategori aktivitas fisik (MET-menit/minggu). Berdasarkan data, hanya terdapat beberapa responden yang melakukan aktivitas fisik secara teratur, sebagian responden yang lain memiliki frekuensi yang sangat kecil ( $1 \mathrm{x} /$ minggu). Semakin intensif aktivitas akan membuat kontrol gula darah dan sensitivitas insulin semakin baik (32).

\section{Hubungan antara tingkat pendidikan dengan kontrol gula darah (HbA1C)}

Tingkat pendidikan dengan kontrol gula darah (HbA1C) pada penelitian ini secara statistik tidak signifikan. Hasil ini berbeda dengan beberapa penelitian sebelumnya $(19,32)$ yang menyatakan bahwa kontrol gula darah lebih baik pada orang dengan tingkat pendidikan yang lebih tinggi. Namun, beberapa penelitian menyatakan bahwa jenis pendidikan yang memberikan pengaruh signifikan terhadap kontrol gula darah. Pendidikan yang tinggi belum tentu menjamin sikap responden yang lebih baik terkait dengan kontrol gula darah. Hal ini dijelaskan oleh PERKENI yang menyatakan bahwa edukasi (pendidikan) secara individual dan pendekatan berdasarkan penyelesaian masalah merupakan inti keberhasilan perubahan perilaku (33). Perubahan perilaku inilah yang akan menentukan sikap responden terkait dengan kontrol gula darah.

\section{Analisis multivariat}

Setelah melakukan penyesuaian dengan semua variabel yang ada, beberapa variabel tetap tidak memiliki hubungan signifikan dengan kontrol gula darah. Hubungan yang signifikan untuk variabel jadwal makan membuktikan bahwa jadwal makan berhubungan langsung dengan kontrol gula darah. Jadwal makan 
yang tidak sesuai akan berpengaruh langsung terhadap kontrol gula darah yang buruk, walaupun terdapat faktor lain yang mengganggu atau mempengaruhi kontrol gula darah. Berbeda dengan variabel asupan IG dan BG, yang pada uji bivariat kedua variabel ini berhubungan signifikan dengan kontrol gula darah, tetapi setelah dikontrol dengan variabel lain, hubungannya melemah. Hal ini membuktikan bahwa asupan IG dan BG masingmasing tidak berhubungan langsung dengan kontrol gula darah. Artinya, terdapat faktor lain yang menjadi perantara hubungan asupan IG dan BG dengan kontrol gula darah.

\section{SIMPULAN DAN SARAN}

Terdapat hubungan antara asupan IG, BG, dan jadwal makan terhadap kontrol gula darah. Namun, tidak terdapat hubungan antara lama terdiagnosis DM, status gizi, aktivitas fisik, dan tingkat pendidikan dengan kontrol gula darah. Konsultasi diet secara rutin sangat baik untuk perubahan sikap dan perilaku jangka panjang. Kerjasama antartenaga kesehatan memegang peranan penting dalam perubahan sikap dan perilaku pasien sebagai dukungan yang harus dilakukan secara terus menerus. Peningkatan kerjasama diperlukan untuk menjaring pasien DM yang tidak/belum pernah mendapat pengetahuan tentang gizi.

\section{RUJUKAN}

1. International Diabetes Federation. Panduan global untuk diabetes melitus tipe 2. Brussels: IDF; 2005.

2. [ADA] American Diabetes Association. Standards of medical care in diabetes. Diabetes Care 2010;33(Supplement 1):S11-61

3. Benoit SR, Fleming R, Philis-Tsimikas A, Ji Ming. Predictors of glycemic control among patients with type 2 diabetes: a longitudinal study. BMC Public Health 2005;5:36.

4. Marshall JA, Bessesen DH, Hamman RF, Denver CO. Dietary correlations of fasting insulin levels in non-diabetics. Boston: ADA; 1994.

5. Liu S, Manson JE, Stamfer MJ, Hu FB, Giovannucci E, Willet WC, et al. A prospective study of whole- grain and risk of type 2 diabetes melitus in US women. Am J Public Health 2000;90(9):1409-15.

6. Meyer KA, Kushi LH, Jacobs Jr DR, Slavin J, Sellers TA, Folsom AR. Carbohydrates, dietary fiber, and incident type 2 diabetes in older women. Am J Clin Nutr 2000;71(4):921-30.

7. Colombani PC. Glycemic index and load-dynamic dietary guidelines in the context of diseases. Physiol Behav 2004;83(4):603-10.

8. Powell KF, Holt Susanna HA, Miller JCB. International table of glycemic index and glycemic load values: 2002. Am J Clin Nutr 2002;76:5-56.

9. Willett W, Manson J, Liu S. Glycemic index, glycemic load, and risk of type 2 diabetes. Am J Clin Nutr 2002;76(1):274S-80S.

10. Ainsworth BE, Haskell WL, Whitt MC, Irwin ML, Swartz AM, Leon AS, et al. Compendium of physical activities: an update of activity codes and MET intensities. Med Sci Sports Exerc 2000;32(9 Suppl):S498-504.

11. National Institute for Health and Care Excellence (NICE). Blood glucose lowering therapy for type 2 diabetes. [series online] 2014 [cited 20 Juli 2013]. Available from: URL: http://pathways.nice.org.uk/ pathways/diabetes

12. Murakami K, Sasaki S, Takahashi Y, Okubo H, Hosoi Y, Kayama F, et al. Dietary glycemic index and load in relation to metabolic risk factors in Japanese female farmers with traditional dietary habits. Am J Clin Nutr 2006;83(5):1161-9.

13. Opperman AM, Venter CS, Oosthuizen W, Thompson RL, Vorster HH. Meta-analysis of the health effects of using the glycaemic index in meal-planning. Br J Nutr 2004;92(3):367-81.

14. UK Prospective Diabetes Study (UKPDS) Group. Association of glycaemia with macrovascular and microvascular complications of type 2 diabetes: prospective observational study. BMJ 2000;321(7258):405-12.

15. Vrolix R, Mensink RP. Effects of glycemic load on metabolic risk markers in subjects at increased risk of developing metabolic syndrome. Am J CLin Nutr 2010;92(2):366-74. 
16. Livesey G, Taylor R, Hulshof T, Howlett J. Glycemic response and health-a systematic review and meta-analysis: relations between dietary glycemic properties and health outcomes. Am J Clin Nutr 2008;87(1):258S-268S.

17. Dewi RP. Faktor risiko perilaku yang berhubungan dengan kadar gula darah pada penderita diabetes melitus tipe 2 di RSUP Kabupaten Karanganyar. Jurnal Kesehatan Masyarakat 2013;2(1).

18. Rahmawati, Aminuddin S, Hidayati H. Pola makan dan aktivitas fisik dengan kadar glukosa darah penderita diabetes melitus tipe 2 rawat jalan di RSUP Dr. Wahidin Sudirohusodo Makassar. Media Gizi Masyarakat Indonesia 2011;1(1):52-58.

19. Adham M, Froelicher ES, Batieha A, Ajlouni K. Glycaemic control and its associated factors in type 2 diabetic patients in Amman, Jordan. East Mediterr Health J 2010;16(7):732-9.

20. Verma M, Paneri S, Badi P, Raman. Effect of increasing duration of diabetes mellitus type 2 on glycated hemoglobin and insulin sensitivity. Indian J Clin Biochem 2006;21(1):142-146.

21. Saydah SH, Fradkin J, Cowie CC. Poor control of risk factors for vascular disease among adults with previously diagnosed diabetes. JAMA 2004;291(3):335-42.

22. Khattab M, Khader YS, Al-Khawaldeh A, Ajlouni K. Factors associated with poor glycemic control among patients with type 2 diabetes. J Diabetes Complications 2010;24(2):84-9.

23. Nichols GA, Hillier TA, Javor K, Brown JB. Predictors of glycemic control in insulin-using adults with type 2 diabetes. Diabetes Care 2000;23(3):273-7.

24. Darmono. Pengaturan pola hidup penderita diabetes untuk mencegah komplikasi kerusakan organorgan tubuh [Pidato Pengukuhan Guru Besar Ilmu Penyakit Dalam Fakultas Kedokteran Universitas Diponegoro]. Semarang: Universitas Diponegoro; 2005.
25. Song MK, Bae JW, Kim YH, Chung S. Hemoglobin $\mathrm{A} 1 \mathrm{C}$ in the screening of obesity related disease in children and adolescents. Ann Pediatr Endocrinol Metab 2012;17(2):92-99.

26. Koga M, Matsumoto S, Saito H, Kasayama S. Body mass index negatively influences glycated albumin, but not glycated hemoglobin, in diabetic patients. Endocrine Journal 2006;53(3):387-391.

27. Dalawa FN, Kepel B, Hamel R. Hubungan antara status gizi dengan kadar gula darah puasa pada masyarakat Kelurahan Bahu Kecamatan Malayang Manado. Ejournal Keperawatan 2013;1(1).

28. Dunstan DW, Daly RM, Owen N, Jolley D, de Courten M, Zimmet P, et al. High-intensity resistance training improves glycemic control in older patients with type 2 diabetes. Diabetes Care 2002;25(10):1729-36.

29. Boule NG, Haddad E, Kenny GP, Wells GA, Sigal RJ. Effects of exercise on glycemic control and body mass in type 2 diabetes melitus: a meta analysis of controlled clinical trials. JAMA 2001;286(10):121827.

30. Dunstan DW, Daly RM, Owen N, Jolley D, Vulikh E, Zimmet P, et al. Glycemic control following supervised training in older individuals with type 2 diabetes. Diabetes Care 2005;28(1):3-9.

31. Locke CT, Bell RC, Myers AM, Harris SB, Evvlestone NA, Rodger NW, et al. Controlled outcome evaluation of the first step program: a daily physical activity intervention for individuals with type 2 diabetes. Int J Obes Relat Metab Disord 2004;28(1):113-9.

32. Bweir S, Al-Jarrah M, Almalty AM, Maayah M, Smirnova IV, Stehno-Bittel L, et al. Resistance exercise training lowers $\mathrm{HbA} 1 \mathrm{C}$ more than aerobic training in adults with type 2 diabetes. Diabetol Metab Syndr 2009;1:27.

33. Perkumpulan Endokrinologi Indonesia. Konsensus pengelolaan dan pencegahan diabetes melitus tipe 2 di Indonesia. Jakarta: PERKENI; 2011. 